\title{
Review of Till Düppe and Ivan Boldyrev's (eds.) Economic Knowledge in Socialism, 1945-89. Durham, NC: Duke Uni- versity Press, 2019, 321 pp.
}

\author{
MARTA PODEMSKA-MIKLUCH \\ Gustavus Adolphus College
}

Economic Knowledge in Socialism, 1945-89, edited by Till Düppe and Ivan Boldyrev, is a collection of twelve essays exploring the discussions and challenges of economic scholarship produced in the communist regimes of the Eastern Bloc. In putting together this excellent collection, Düppe and Boldyrev build on their extensive expertise in the history and philosophy of science. The essays are diverse in terms of their historical and geographic context and in terms of the dynamics, and the unique challenges, they capture. Each essay can be interpreted as a study of two tightly connected themes: the influence of the socioeconomic regime on the direction of economic scholarship and the institutional challenges confronted in the creation of economic knowledge. Effectively, each chapter provides a unique perspective on the importance of the institutional context in which economic knowledge is produced and the role that the consolidation of political power plays in shaping social science. These contributions make the collection an intellectual thrill for scholars interested in the influence of politics on economic scholarship, the history of socialism, and the history of economic thought. The volume will be easily accessible to readers already familiar with the post-World War II history of Eastern and Central Europe; though, others might need to occasionally refer to additional sources, as the chapters vary in the knowledge they require for full comprehension.

The book is divided into four parts, each part consisting of three chapters. The first part, Discourses, includes discussions of (1) strategies for wage setting in the early years of post-war Hungary (Martha Lampland), (2) the role of political patronage in the development of reform-oriented economic scholarship in Hungary, from 1953 to mid-1970s (György Péteri), and (3) the public engagement of Czechoslovak economists in the explanation and defense of proposed economic reforms in the 1960s (Vítězslav Sommer). The second part, Doctrines, offers (1) a discussion of how leading Soviet economists contributed to the ideological discourse 
starting at the time of the October Revolution until the early 1970s (Oleg Ananyin and Denis Melnik), (2) an overview of how the anti-statist direction in the political economy of socialism was squashed in the Soviet Union in the early 1970s (Yakov Feygin), and (3) an examination of how the argument for the over-development of the Soviet military emerged and fared (Adam E. Leeds). The third part, Techniques, discusses (1) the evolving role that mathematical methods and systems science-economic cybernetics-played in economic planning in the Soviet Union, from the 1960s until perestroika (Richard E. Ericson), (2) the introduction of pattern recognition and algorithmic decision-making into models of a command economy (Olessia Kirtchik), and (3) the involvement of Soviet systems analysts in international development projects as a source of political dissensus (Egle Rindzevičiūtè). The final part, The International, has chapters on (1) the growing disillusionment with the prospects of a Soviet-led development in decolonizing countries (Chris Miller), (2) neoclassical economics as economics of socialism and the evolving meaning of structural adjustment, focusing on Yugoslav economists (Johanna Bockman), and (3) the influence of convergence theory-predicting eventual Eastern-Western convergence-on perestroika (Joachim Zweynert).

Here, I will focus on three chapters-those by Péteri, Ericson, and Kirtchik. These chapters yield interesting insights into some of the main themes of the volume: the specific challenges faced by economists in communist regimes and the importance of being sensitive to the institutional context at hand.

In the introduction, the editors caution readers to avoid slipping into a comparative mode, as doing so might favor questions only relevant to Western economies, while leaving out phenomena that were unique to socialism. This point is illustrated particularly well by the discussion of academic patronage in the second chapter of the volume, "By Force of Power: On the Relationship between Social Science Knowledge and Political Power in Economics in Communist Hungary". The author, György Péteri, devotes this chapter to the analysis of the relative autonomy of economic research observed in Hungary after 1953. Péteri attributes this autonomy to the influence of István Friss, who was a member of the Central Committee of the Communist Party from 1948 to the end of his life in 1978, and the head of the economic policy department of the Central Committee between 1948 and 1954. Friss was an influential member of the high echelons of the communist regime, with carefully accumulated 
connections, reputation, and prestige backing his powerful position. Péteri paints Friss as a passionate intellectual with a deep devotion to scientific economic knowledge and empiricism, passions that prompted Friss to create the Institute of Economics of the Academy of Sciences. The Institute became central to Friss' influence over the production of economic research and to the protection he granted to his protégées. In the author's account, it was Friss' political influence that, through the force of power, enabled the international success of János Kornai's scholarship, a success that would not be possible through the power of thought alone.

Péteri opens the chapter with the assertation that while patronage of academic enterprises is necessary in any economic system, the state socialist order magnifies that need. As Péteri acutely observes, the peculiarities of socialism generated the phenomenon of the patron's dilemma: the more the patron invests in the protection of his clientele, the more he undermines his own position and reputation that enabled him to offer protection in the first place. The patron's dilemma captures the dynamics of the monocentric, consolidated power structure of socialist regimes. This brilliant observation is made almost in passing, with the chapter far more focused on the significance of Friss' influence that, in the author's eyes, had been downplayed in the literature. Because of this focus, the author seems to miss the importance of loyalty in patronage relationships. Péteri interprets Friss' protection as motivated by the joy derived from the professional success of his protégées. But surely there was more to that motivation. The loyalty generated by the protection of controversial revisionist economists must have contributed to Friss' long-term position as the head of the Institute of Economics of the Academy of Sciences. Non-controversial economists would have had far less need to remain loyal to Friss than those whose livelihoods depended on his protection. The exchange of protection for loyalty seems a far stronger interpretation of academic patronage in a system of consolidated state power.

While the phenomenon of the patron's dilemma might be specific to autocratic regimes, other challenges encountered by economists in socialist states seem more universal, though to be sure, their frequency and intensity might vary between autocracies and democracies. One such challenge is the interaction between policy advice and political interests. To be effective, change in public policy must alter economic and political interests, hence the frequent disappointment of economists in having their policy ideas thwarted by political reality, as captured by Richard Ericson's chapter on the System for Optimal Functioning of the Economy 
(SOFE). While other chapters in the volume attribute the resistance to reforms mainly to ideology, Ericson counts political obstacles as equally, if not more, important. SOFE was developed in response to the weaknesses of Bolshevik planning. It was an attempt to introduce mathematical methods and systems science (economic cybernetics) as a replacement to direct management decisions, substituting algorithms for planners. Effectively, full adoption of SOFE implies substantial reduction in the political influence of those in control of resource and product allocation. The 'transitional losses trap'-the potential loss of privileges resulting from their position within the regime-explains the political resistance to its implementation. Yet, as Ericson notes, the biggest challenge to SOFE lied not in the ideological and political objections to its implementation but in the unresolved issues of acquiring and processing necessary information and of mitigating deep incentive compatibility issues. One is left wondering how a three-decade long intellectual effort could be committed to a program that was so inherently flawed and unworkable and why Soviet scholars continued its development despite complete awareness of the program's weaknesses. Is it possible that they had little choice but to build this house of cards? Or were they driven by a well-hidden political realism? In either case, they were rewarded for the intricacies of their designs, and for the smokescreen they provided to the political regime.

Olessia Kirtchik's chapter on the work of Soviet scientists in pattern recognition and economic disequilibrium amplifies some of the themes captured by Ericson; in particular, it highlights the extent of the intellectual effort that went into the development of cybernetics in the Soviet Union. However, Kirtchik pays less attention to how this scholarship fit into the institutional landscape. This leads her to a comparison between, on the one hand, the development of cybernetics in the Soviet Union and, on the other, the development of algorithms and the recent adoption of machine learning in the West. But any such similarity must surely be superficial given the dramatic difference in purposes for which these tools were designed and used. In the Soviet Union, complex adaptive systems were supposed to teach workers to respond to top-down commands. In the West, they aggregate and process information for the purpose of improving customer experience. The former attempted to improve upon top-down control processes, where the direction of change originated from a single source. The latter attempts to improve on the emergent processes of knowledge production and the direction of change is crowdsourced. 
While I cannot discuss all chapters in this short review, I hope that my comments will encourage readers to explore the collection in its entirety. I share the editors' hope and desire that the volume will encourage further research on the dynamics and challenges entrenched in the scholarly pursuits under socialism. For scholars who endeavor on this quest, Düppe and Boldyrev's volume will serve as an invaluable footprint.

Given the budding nature of this field of study, and the many topics that had to be left out from the current volume, the editors might want to consider subsequent collections. Should they do that, I have three suggestions. First, I would suggest adopting a more descriptive title. The current title falls short of capturing the essence of the contribution. This is not a book about economic knowledge or the history of economic thought. Rather, this is a book about the dynamics of producing economic scholarship under a totalitarian regime, the unique (and the more universal) challenges encountered by scholars in such conditions, and the role the institutional environment plays in shaping the selection of scholarly pursuits. A more descriptive title for the subsequent volumes would be "The Creation of Economic Knowledge in Socialism". Second, given the diversity of chapters, the book would benefit from a longer introduction, providing a context for each chapter and explaining how each chapter fits with the theme of the book. A longer introduction would provide readers with alternative approaches to sampling the chapters: for example, the early versus the final decades of the Soviet Bloc, or the Soviet Union versus the Republics versus the Satellites. Third, a more careful editorial and cross-disciplinary peer-review process could have helped avoid some mistakes. For example, in the first chapter, Martha Lampland describes the economy of Hungary prior to 1948 as capitalist while simultaneously recognizing that it was characterized by state control of the means of production. These oversights do not take much away from the core value of the book. Düppe and Boldyrev, and their collaborators, must be commended for the excellent volume they have produced and should feel encouraged to continue on this path.

Marta Podemska-Mikluch is an Associate Professor of Economics at Gustavus Adolphus College. Using the analytical approach of Entangled Political Economy, Podemska-Mikluch's research analyzes the role entrepreneurship plays at the intersection of divergent institutional settings and the role regulations play in fostering and curtailing innovation. Originally from Poland, Podemska-Mikluch earned her Ph.D. in Economics from George Mason University, M.S. in Applied Economics from St. Cloud State 
University, and B.A. in Political Science also from St. Cloud State. Podemska-Mikluch is the founding director of the Entangled Political Economy Research Network that brings together more than 80 scholars interested in advancing the novel approach of Entangled Political Economy. Contact e-mail: <mpodemsk@gustavus.edu> Website: <www.podemska.com> 